\title{
がん化学療法制吐剂適用時の有害事象調査
}

\author{
吉野真樹 ${ }^{*}$, 貝瀬眞由美，田中佳美，長井春樹 \\ 新潟県立がんセンター新潟病院薬斉部
}

\section{Survey on Adverse Events with Use of Antiemetics during Anti-cancer Chemotherapy}

\author{
Masaki Yoshino*, Mayumi Kaise, Yoshimi Tanaka and Haruki Nagai \\ Pharmaceutical Division, Niigata Prefectural Cancer Center Hospital
}

\author{
[ Received A ugust 30, 2010 )
}

Niigata Cancer Center Hospital has made efforts to standardize the use of antiemetics and the present study was performed to investigate adverse events occurring after their use. In 373 patients who received treatment regimens with a high risk of vomiting during the period from A pril 2008 to March 2009, we investigated the occurrence of nausea and vomiting and other adverse events. The incidence of delayed nausea was high (63.3\%). Other adverse events were: constipation (40.5\%), blood pressure elevation (42.4\%), and fatigue (43.4\%). The number of delayed nausea patients in whom constipa tion occurred increased after receiving chemotherapy regimens containing cisplatin. A Iso in an analysis of factors influencing the cause of delayed nausea, the following were identified as significant factors: onset of constipation after chemotherapy (odds ratio, 3.303; 95\% confidence interval, 1.990-5.484) and regimens containing cisplatin (odds ratio, 3.505; $95 \%$ confidence interval, 2.046-6.003).

When both a 5 - HT 3 receptor antagonist and high-dose steroid are prescribed for patients receiving regimens with a high risk of vomiting, we should pay careful attention to adverse events such as delayed nausea, constipation, blood pressure elevation, and fatigue. In addition, since constipation following chemotherapy and the use of regimens containing cisplatin are risk factors for delayed nausea, it is essential to take appropriate actions based on an evaluation of clinical symptoms relevant to the use of antiemetics.

Key words — cancer chemotherapy, practice guideline, antiemetics, delayed nausea, adverse events, constipation

緒言

がん化学療法の薬物有害反応において悪心・嘔吐は患 者にとって最も辛い症状のひとつである.患者のQuality of life(以下，QOL と略す)を維持し治療を継続するため には，症状をできる限り軽減することが極めて重要であ る. 新潟県立がんセンター新潟病院(以下, 当院と略す) では，制吐剂処方については米国臨床腫瘍学会(ASCO： A merican Society of Clinical Oncology)などの制吐療法ガ

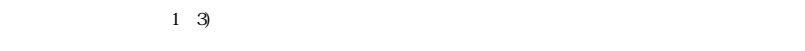
すめてきだ).

一方 , ガイドラインに従った治療においても悪心・嘔 吐が十分に制御できない症例が存在すること, 悪心・嘔 吐以外の有害事象の発現にて治療継続に難渋する症例が 見受けられ，患者のQOL が十分に担保されていない可
能性が推察された . また，わが国では制吐療法適用時の 有害事象に関する報告はほとんどない，乥こで本研究で は，当院においてこれまでに使用してきた制吐剂処方の 問題点を把握するため, 悪心・嘔吐ほか, 適用後問題と なった有害事象について調査した。

方法

1. 対象レジメン

対象期間(2008年 4 月から 2009 年 3 月)における参照 ガイドラインは National Comprehensive Cancer Network (NCCN)2005年度版であり，また併用レジメンにおける 嘔吐リスクのレベル補正法は Hesketh らの方法坏による ものである .これらによって割り付けられる高度嘔吐リ スク群(90\% 以上, Level 5)に該当するレジメン群を対象 とした .

\section{新潟県新潟市中央区川岸町 2-15-3}


医療薬学 Jpn. J. Pharm. Health Care Sci.

2. 制吐剂処方

高度嘔吐リスク群の制吐斉処方は, Day 1 にグラニセ 卜ロン塩酸塩注射液 $3 \mathrm{mg}+$ デキサメタゾン注射 20 mg, Day 2-3にデキサメタゾン $8 \mathrm{mg}$ (注射もしくは内服) とした.

\section{3. 対象患者}

2008年 4 月から 2009 年 3 月までの間において, 対象 レジメンの化学療法を施行された 373 名を対象患者とし た.ガイドラインでは放射線療法誘発性嘔吐の制吐療法 についても提言があるが，本調査の対象として，放射線 併用化学療法を施行された患者は除外した . プロトコー ルに治療を意図するステロイド斉の投与が規定されてい る造血器腫瘍レジメンの適用患者も除外した . 繰り返し の化学療法では, 前治療の有害事象による予測性悪心 ・ 嘔吐もしくは予防措置などが発生し, 有害事象の発現に 影響を与える .これらの要因を除外するため, すべて初 回化学療法時のみを調査対象とした。

なお, 本研究は新潟県立がんセンター新潟病院の倫理 委員会の承認を得て行った(承認番号 : 2010-32, 研究番 号 : 308 「゙ん化学療法制吐剂使用基準適用後の評価と 問題点の把握」).

\section{4. 調査方法}

患者基本情報，処方記録などは電子カルテより抽出し た . 悪心・嘔吐ほか, 有害事象項目は薬剂管理指導記録 および電子カルテ記録(ともに有害事象 Grading 記載方 式：CTCAE ver.3.0)を後方視的に調査した . 急性悪心 ・ 嘔吐の定義は投与後 24 時間以内のイベントとし，24 時 間後から最大 1 週間までの間におけるイベントを遅発性 悪心・嘔吐とした，兴の他の消化器症状(便秘, 下痢, 吃逆, 胃痛)および疲労, 不眠, 頭痛などについては, 「症状なし」から新たに発現した症例を抽出した．血圧 上昇および血糖值上昇については, 既往疾患, 継続使用 薬剂によらずベースラインからの上昇傾向を示した症例 を抽出した．血糖值上昇症例は測定を実施した 24 症例 のみを対象とした . 有害事象項目の追跡期間は化学療法 開始日から最大 1 週間までとした .

\section{5. 統計解析}

統計学的検討は統計解析ソフトウェア「Dr.SPSS II 11.0 J for Windows」((株)エス・ピー・エス・エス)を用いて解 析した. 遅発性悪心発現の有無別での便秘発現症例の比 較にはX ${ }^{2}$ 検定を用いた。遅発性悪心発現の危険因子の 検討は, 性別・年齢・消化器がんなどの分析項目を含 め, まず単変量解析を実施し，光の結果を基に交絡を調 整するため多変量解析を実施した．危険率 $5 \%$ 未満を有 意水準とした
結果

1. 症例背景

対象症例背景を表 1 に示す．急性嘔吐対策は 5-HT 3 受容体拮抗薬(グラニセトロン塩酸塩注射液 $3 \mathrm{mg}$ )373例 (100\%)，デキサメタゾン注射 373 例(100\%)，光の他ド パミン受容体拮抗薬などが 89 例(23.9\%)であった．遅発 性嘔吐対策は 5-HT 3 受容体拮抗薬(グラニセトロン塩酸 塩注射液, 塩酸グラニセトロン内服, オンダンセトロン 内服)63例(16.9\%)，デキサメタゾン注射・内服 373 例 (100\%)，光の他ドパミン受容体拮抗薬などが 30 例(8\%) であった .デキサメタゾン平均使用量は，急性嘔吐対策 で $18.3 \mathrm{mg}$ ，遅発性嘔吐対策で $8.2 \mathrm{mg}$ であった．突出性 悪心・嘔吐に対する救援治療では, 併用処方を含め最も 処方が多かった薬剂分類は 5-HT 3 受容体拮抗薬 181例 であった . 次いで，ドパミン受容体拮抗薬 151 例 , デキ サメタゾン113例であった .

\section{2. 有害事象の発現状況}

制吐剂適用時の有害事象の発現状況を表 2 に示す．急 性の悪心・嘔吐は光れ光れ 23例(6.2\%)，6例(1.6\%)，

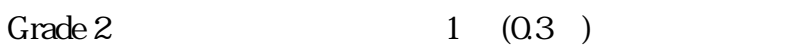
た . 遅発性の悪心・嘔吐は光れぞれ 242例(63.3\%)，67 例(17.9\%)，Grade 2 以上の症例は悪心で 56 例(15\%)，嘔 吐で 12 例(3.2\%)ずつ認められた . 悪心 ・嘔吐以外の消 化器症状の発現は, 便秘 151 例(40.5\%), 下痢 45 例(12.1 $\%)$, 吃逆 34 例(9.1\%), 胃痛 1例(0.3\%)であった . 血圧 上昇が 158 例(42.4\%)に認められ，Grade 3 に該当する重 篤な症例を 3 例認めた . 血糖值上昇は血糖值を測定した 24 例全例に発現した .インスリンによる補正を実施し た症例を含め，いずれも Grade 2 以上の重症度であっ た．弚の他臨床事項として，疲労が 162 例(43.4\%)に認 められた．少数例として，不眠(0.3\%)，頭痛(0.5\%)，口 内乾燥 $(0.5 \%)$ ，ほてり(0.5\%)を認めたが，いずれも一過 性でかつ軽度の症状であった。

3. 化学療法後の便秘の発現状況と遅発性悪心との関連 遅発性悪心発現の有無で症例を分け, 各々の便秘発現 症例を集計した .さらに化学療法の種別での分布を見る ため，「シスプラチン含有レジメン」,「抗がん斉連日投 与レジメン」の2項目について該当の有無で分類した(図 1).「遅発性悪心あり」の 241 症例中 121 例において便 秘を認め,「遅発性悪心なし」の 132 症例中 30 例の便秘 発現件数に比べ有意に多かった $(p<0.001)$. また , 「シス プラチン含有レジメン $(+)$ 抗がん斉連日投与レジメン $(+)\lrcorner$ おび「シスプラチン含有レジメン $(+)$ 抗がん剂 連日投与レジメン( - )」において遅発性悪心および便秘 の発現症例が多かった(各 40 例，51例). 


\begin{tabular}{|c|c|}
\hline 調査項目 & 対象症例 $(n=373)$ \\
\hline 年齢（歳）（median:min-max） & $64: 13-82$ \\
\hline 性別（男性/父性） & $186 / 187$ \\
\hline \multicolumn{2}{|l|}{ がん種 } \\
\hline 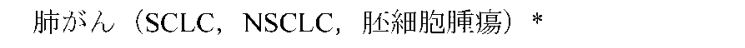 & 117 \\
\hline 消化器がん（岌, 食道, 大腸がん） & 115 \\
\hline 婦人科がん（子宫顕・体がん，卵宩がん） & 141 \\
\hline \multicolumn{2}{|l|}{ 急性啀吐対策処方 } \\
\hline 5-HT3 受容体拈抗薬 & $373(100 \%)$ \\
\hline デキサメタゾン & $373(100 \%)$ \\
\hline その他（ドパミン受谷体怙抗薬など） & $89(23.9 \%)$ \\
\hline デキサメタゾン半均使用量（min-max） & $18.3 \mathrm{mg} \quad(8-20 \mathrm{mg})$ \\
\hline \multicolumn{2}{|l|}{ 荤発性嘔吐対策処方 } \\
\hline 5-HT3 受容体怙抗薬 & $63(16.9 \%)$ \\
\hline デキサメタゾン & $373(100 \%)$ \\
\hline その他（ドパミン受容体拮抗楽など） & $30(8 \%)$ \\
\hline デキサメタゾン平均使用量（min-max） & $8.2 \mathrm{mg}(8-20 \mathrm{mg})$ \\
\hline \multicolumn{2}{|l|}{ 救援治療処 $J_{j}($ (作用処 Jj含志) } \\
\hline 5-HT3 受容休拈抗薬 & 181 \\
\hline デキサメタゾン & 113 \\
\hline ドパミン受容体怙抗薬 & 151 \\
\hline $\begin{array}{l}\text { その他(フェノチアジン系, ベンゾジアゼピン系, } \\
\text { H2 受容体怙抗薬, プロトンボンプインヒビターほか) }\end{array}$ & 103 \\
\hline
\end{tabular}

*SCLC：小細胞肺がん， NSCLC：非小細胞肺がん

4. 遅発性悪心発現症例の臨床項目についての要因分析 悪心の発現には性別・年齢・消化器がんといった要因 が寄与することはすでに得られている知見であるが，光 の交絡を調整するため分析項目としてあげた . 図 1 にお いて示された通り，遅発性悪心発現には化学療法の種別 および便秘による影響が推察されたため, 分析項目とし てあげた．以上の項目を踏まえ単变量解析を実施し，光 の結果を基に交絡を調整するため多変量解析を実施し た. 臨床項目別の遅発性悪心発現頻度とオッズ比を表 3 に示した . 単変量ロジスティック回帰分析により検討し た結果，「消化器がん」(オッズ比：1.853，95\% 信頼区間 1.140-3.010, p<0.05), 「化学療法後の便秘発現」(オッズ 比 : 3.428, 95\% 信頼区間 2.123-5.535, p<0.001), 「シ スプラチン含有レジメン」(オッズ比 : $3.639,95 \%$ 信頼 区間 2.326-5.693, p < 0.001)が有意な因子として抽出さ れた . 多変量ロジスティック回帰分析により検討した結 果を表 4 に示す .「化学療法後の便秘発現」(オッズ比 : 3.303，95\% 信頼区間 1.990-5.484, p<0.001)，「シスプ ラチン含有レジメン」(オッズ比 : $3.505,95 \%$ 信頼区間
2.046-6.003, p<0.001)が有意な因子として抽出された .

\section{考察}

2010 年以降より，新規制吐剂(Neurokinin-1(NK 1)受容 体拮抗薬アプレピタント，第二世代の 5-HT 3受容体拮 抗薬パロノセトロン)か臨床適用可能となり，2010年 5 月には，これらを組み込んだ制吐剤適正使用ガイドライ ンが日本癌治療学会より公表された。当院でも，新たな ガイドラインに基づいた改訂を実施し 2010 年 7 月より 運用を開始している.われわれはこれに先立ち，これま で運用してきた制吐斉処方での問題点を把握し，改訂の 根拠となる情報を得ることを目的として調査・検討をす すめた .

今回の調査で, 急性症状発現率は, 悪心で $6.2 \%$, 嘔 吐で $1.6 \%$ であり $90 \%$ 以上の制御率を示した.一方， 遅発性症状発現率は，悪心で 63.3\%，嘔吐で $17.9 \%$ で あり，特に遅発性の悪心の制御率が低値を示し(表 2)， この結果は，Saitoらのの報告と一致するものであった . 
表 2 . 有害事象の発現状況

\begin{tabular}{|c|c|c|c|c|c|c|}
\hline \multirow{2}{*}{$n=373$} & \multicolumn{3}{|c|}{ CTCAE ver.3.0 Grade } & & \multirow{2}{*}{$\begin{array}{c}\text { All Grades } \\
(\%)\end{array}$} & \multirow{2}{*}{$\begin{array}{c}\text { Grade } 2 \leqq \\
(\%)\end{array}$} \\
\hline & 1 & 2 & 3 & 4 & & \\
\hline \multicolumn{7}{|l|}{ 悪心・嘔吐 } \\
\hline 急性览心 & 22 & 1 & 0 & 0 & 6.2 & 0.3 \\
\hline 怘性煰吐 & 5 & 1 & 0 & 0 & 1.6 & 0.3 \\
\hline 遅発性悪心 & 186 & 46 & 10 & 0 & 63.3 & 15 \\
\hline 遅発吽嘔叶。 & 55 & 11 & 1 & 0 & 17.9 & 3.2 \\
\hline \multicolumn{7}{|c|}{ その他の消化器症状 } \\
\hline 便秘 & 128 & 23 & 0 & 0 & 40.5 & 6.2 \\
\hline 下痢 & 39 & 4 & 2 & 0 & 12.1 & 1.6 \\
\hline 吃逆 & 22 & 11 & 1 & - & 9.1 & 3.2 \\
\hline 胃痛（疼痛） & 1 & 0 & 0 & 0 & 0.3 & 0 \\
\hline 血圧上㫒 & 123 & 32 & 3 & 0 & 42.4 & 9.4 \\
\hline 血糖值上昇* & 0 & 13 & 11 & 0 & - & - \\
\hline 疲觉 & 149 & 11 & 2 & 0 & 43.4 & 3.4 \\
\hline 不胀 & 0 & 1 & 0 & 0 & 0.3 & 0.3 \\
\hline 顽痛（将痛） & 1 & 1 & 0 & 0 & 0.5 & 0.3 \\
\hline 口内乾燥 & 2 & 0 & 0 & - & 0.5 & 0 \\
\hline ほてり & 2 & 0 & 0 & - & 0.5 & 0 \\
\hline
\end{tabular}

* 血糖值測定を実施した 24 症例のみ文刘象とした

A SCO 2006年版のガイドライン(http : / / www.nccn.org) でも，オンダンセトロンやグラニセトロンなどの 5-HT 3拮抗薬は, 急性悪心・嘔吐には有効だが, 遅発期の悪 心・嘔吐には効果か認められないことに言及しており， 遅発期での症状コントロールにエビデンスがある $3^{6,7) ア フ ゚ ~}$ レピタントやパロノセトロンなどの新規制吐療法への期 待を含め, 遅発期における制吐療法においては今後もさ らなる検討が必要と考える。

化学療法後の便秘の発現は約 40\% の症例において認 められた(表 2). 既往疾病などの直接の原因もあるが， 化学療法に使用した薬剂によって二次的に便秘が発現し た可能性も否定できない，プラチナ系抗がん阁や 5-HT 3受容体拮抗薬は消化管運動を停滞する作用が報告され ており，弚の寄与も大きいと考える ${ }^{8.9}$. また，当院にお ける救援治療は 5-HT 3受容体捛抗薬の処方例が多い(表 1)ため，予防投与からの継続使用による 5-HT 3受容体 捛抗薬由来の便秘の発現の可能性は高い，図 1 で示され たように，遅発性悪心の発現は, シスプラチン含有レジ メンの施行症例で化学療法後に便秘が発現した症例にお いて特に多い傾向を認めた .さらに遅発性悪心の要因に ついて多変量ロジスティック回帰分析にて検討した結 果, 「化学療法後の便秘発現」,「シスプラチン含有レジ
メン」が独立した色険因子であることが示された(表 4) . 特に化学療法後に新たに発現した便秘が, 遅発性悪心の 発現に強く関与するという点についてはこれまでに報告 がなく, 新たな知見である . 抗がん阁治療にかかわらず 便秘の存在は悪心に影響することも報告されており ${ }^{10)}$, 便秘の予防・症状コントロールは消化器症状全般のケア において重要と考える.今回得られた知見から，特にプ ラチナ系抗がん斉と 5-HT 3受容体拮抗薬が併用される 高度嘔吐リスクレジメンでは, 化学療法後の便秘が起こ りやすい環境にあり，これが遅発性悪心の発現に影響し ている可能性が高いことが示唆された .

弚の他の有害事象として, 血圧上昇 $(42.4 \%)$, 血糖値 上昇, 疲労(43.4\%), 吃逆(9.1\%)を認めた。血圧および 血糖值上昇は, 全例 Day 1から Day 4の間において症状 が発現し, ステロイド剂投与が終了するDay 4以降に は，おおむねべースラインまで回復した . 疲労の発現は ステロイド斉投与が終了する Day 4以降の症例がほとん どであり, 大量のステロイド剂に暴露された後の離脱症 状も要因のひとつと推察された . 吃逆の発現は特徵的で あり，症例の $94 \%$ は男性・シスプラチン $\left(60-80 \mathrm{mg} / \mathrm{m}^{2}\right)$ 含有レジメン施行例であった . 林ら ${ }^{11}$ は , シスプラチン 化学療法における吃逆の危険因子について検討し，男 
遅発性悪心市り（All Grades）

$\mathrm{n}=241$
遅発性悪心なし $n=132$

便秘あり（All Grades）

121 $30^{*}$

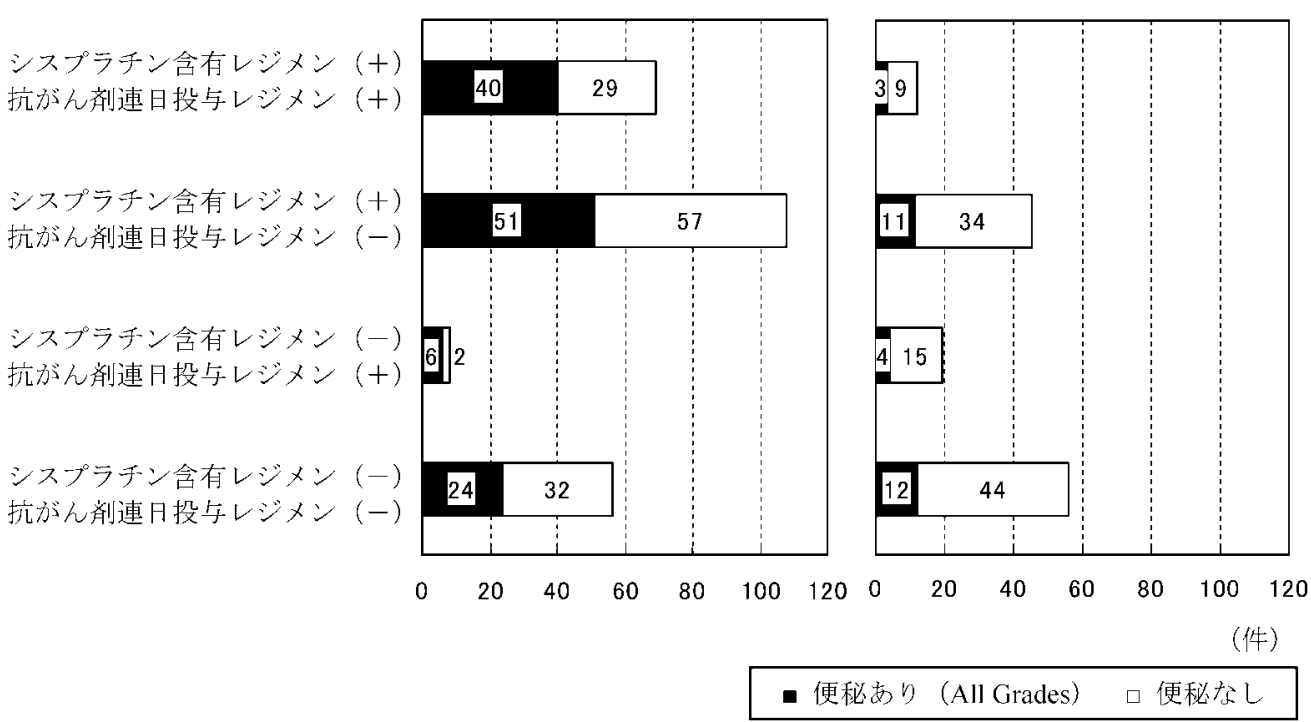

図 1. 化学療法後の便秘の発現状況と遅発性悪心との関連 遅発性悪心発現の有無で症例を分け，各々の便秘発現症例を集計した．さらに化学療法の種別 での分布を見るため，「シスプラチン含有レジメン」,「抗がん剂連日投与レジメン」の 2 項目 について該当の有無で分類した .

${ }^{*} p<0.001$ 遅発性悪化あり群との比較 $\left(X^{2}\right.$ 検定 $)$

表 3 . 遅発性悪心発現症例の臨床項目についての単変量ロジスティック回帰分析

\begin{tabular}{|c|c|c|c|}
\hline 項目（㾟例数） & $\begin{array}{c}\text { 遅発性悪心 } \\
\text { 発現症例数 }(\%)\end{array}$ & $\begin{array}{l}\text { Odds Ratio } \\
(95 \% \text { C.I. * })\end{array}$ & $\mathrm{p}$ \\
\hline 65 歳木満（189） & $127(67.2)$ & $1.258(0.822-1.924)$ & 0.342 \\
\hline 女性（187） & $121(64.7)$ & $1.008(0.66-1.524)$ & 1.000 \\
\hline がん種 & & & \\
\hline 肺がん（117） & $72(61.5)$ & $0.824(0.523-1.296)$ & 0.470 \\
\hline (SCLC，NSCLC，胚細肘腫晹）** & & & \\
\hline 消化器ずん（115） & $85(73.9)$ & $1.853(1.140-3.010)$ & $<0.05$ \\
\hline （胃，食道，大腸がん） & & & \\
\hline 婦人科がん（141） & $84(59.6)$ & $0.704(0.456-1.087)$ & 0.140 \\
\hline （子宮頚・体がん，即栄がん） & & & \\
\hline 化”味療法後の便秘発現（151） & $121 \quad(80.1)$ & $3.428(2.123-5.535)$ & $<0.001$ \\
\hline シスプラチン含有レジメン (234) & $177(75.6)$ & $3.639(2.326-5.693)$ & $<0.001$ \\
\hline 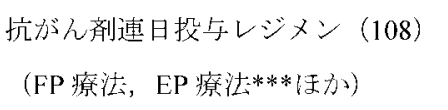 & $77(71.3)$ & $1.53(0.942-2.485)$ & 0.108 \\
\hline
\end{tabular}

* 95\%C.I. : 95\% Confidence Interval

** SCLC：小細胞肺がん，NSCLC：非小細胞肺が九

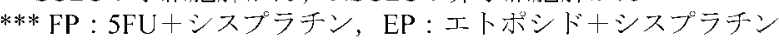


医療薬学 Jpn. J. Pharm. Health Care Sci.

表 4 . 遅発性悪心発現に関連する要因の多変量ロジスティック回帰分析

\begin{tabular}{|c|c|c|}
\hline 要因 & $\begin{array}{l}\text { Odds Ratio } \\
(95 \% \text { C.I. } *)\end{array}$ & $\mathrm{p}$ \\
\hline 65 歳木満 & $1.307(0.796-2.146)$ & 0.290 \\
\hline 女吽 & $1.659(0.950-2.897)$ & 0.075 \\
\hline $\begin{array}{l}\text { 消化器がん } \\
\text { (胃，食道，人腸がん) }\end{array}$ & $1.290(0.677-2.455)$ & 0.439 \\
\hline 化学療法後の便秘発現 & $3.303(1.990-5.484)$ & $<0.001$ \\
\hline シスプラチン含有レジメン & $3.505(2.046-6.003)$ & $<0.001$ \\
\hline $\begin{array}{l}\text { 抗がん剂連日投ケレジメン } \\
\text { (FP 療法, EP 療法**ほかか) }\end{array}$ & $1.366(0.752-2.481)$ & 0.306 \\
\hline
\end{tabular}

* 95\%C.I. : $95 \%$ Confidence Interval

**FP : 5FU+シスプラチン，EP：エトポシド十シスプラチン

性・シスプラチン投与量 $\left(70 \mathrm{mg} / \mathrm{m}^{2}\right.$ 以上 $)$ ・デキサメタゾ ン $16 \mathrm{mg}$ 以上の併用・グラニセトロン $6 \mathrm{mg} /$ Day $の$ 併用 か吃逆の独立した危険因子であると報告しているが，本 調査においてほぼ一致した結果が得られた .いずれの有 害事象も高用量ステロイド阂投与の関与が推察される が, 光の他の多樣な因子か関連している可能性もあり, 本研究で各々の発現要因を詳細に特定することはできな かった．しかし，高用量のステロイド剂を投与する制吐 斉処方ではステロイドの影響は無視できず，少なくとも 本調査で観察された有害事象には配慮する必要があると 考える。

ガイドラインに基づく標準化は推進されるべきもので あるが, 本研究でも示唆された通り, 適用が患者 QOL 向上においてすべて有効ということではなく，現時点で 解消されない側面も多々存在する．したがって，適用後 の評価および有害事象を的確に判断した上での症例ごと の個別対応は重要である . 著者らは，今回得られた知見 から化学療法後に発現する便秘に注目し，患者およびス タッフへの注意喚起と早期における対症療法の検討，次 コースにおける予防的下剂処方の提案などを積極的に行 うこととした . 新規制吐剂パロノセトロンの臨床試験で は主な副作用として便秘が $16.5 \%$ の発現頻度にて報告 されており12)，今後のガイドライン適用においても，便 秘の症状コントロールは重要な位置づけとなる . 個別対 応の部分で薬闵師が積極的に介入することは重要な取り 組みであり，今後も症例の集積・評価を図ることで，患 者の早期回復に貢献していきたい.

\section{引用文献}

1) R.J. Gralla, D. Osoba, M.G. Kris, P. Kirkbride, P.J. Hesketh, L.W.Chinnery, R. Clark-Snow, D.P. Gill, S. Groshen, S. Grunberg, J.M. Koeller, G.R. Morrow, E.A. Perez, J.H. Silber, D.G. Pfister, Recommendations for the use of antiemet- ics: evidence-based, clinical practice guidelines. A merican Society of Clinical Oncology, J. Clin. Oncol., 17 , 29712994 ( 1999).

2) ASHP Therapeutic Guidelines on the Pharmacologic Management of Nausea and Vomiting in A dult and Pediatric $\mathrm{Pa}$ tients Receiving Chemotherapy or Radiation Therapy or Undergoing Surgery, Am. J. Health. Syst. Pharm., 56 , 729764 (1999).

3) Prevention of chemotherapy- and radiotherapy-induced emesis: results of Perugia Consensus Conference. Antiemetic Subcommittee of the Multinational Association of Supportive Care in Cancer (MASCC), Ann. Oncol., 9 , 811-819 (1998).

4) 吉野真樹，圓山優子，がん化学療法制吐剂の適正使用に むけた取り組みー新潟県立がんセンター新潟病院におけ る急性期嘔吐対策の現状 - , 医療薬学, 34, 781-787 (2008).

5) P.J. Hesketh, M.G. Kris, S.M. Grunberg, T. Beck, J.D. Hainsworth, G. Harker, M.S. A apro, D. Gandara, C.M. Lindley, Proposal for classifying the acute emetogenicity of cancer chemotherapy, J. Clin. Oncol ., 15 , 103-109 (1997).

6) M. Saito, K. A ogi, I. Sekine, H. Y oshizawa, Y. Y anagita, H. Sakai, K. Inoue, C. Kitagawa, T. Ogura, S. Mitsuhashi, Palonosetron plus dexamethasone versus granisetron plus dexamethasone for prevention of nausea and vomiting during chemotherapy : a double-blind, double-dummy, randomised, comparative phase III trial, Lancet Oncol., 10, 115124 (2009).

7) H.J. Schmoll, M.S. Aapro, S. Poli-Bigelli, H.K. Kim, K. Park, K. Jordan, J. von Pawel, H. Giezek, T. A hmed, C.Y. Chan, Comparison of an aprepitant regimen with a multipleday ondansetron regimen, both with dexamethasone, for antiemetic efficacy in high-dose cisplatin treatment, Ann. Oncol., 17 , 1000-1006 (2006).

8) 村上通康, 木本国晴, 一藤真, 橋本浩季, 宮宇地徳昌, 平野和加，須藤久実，兵頭祐子，辻文恵，管晋，仙波昌 三，野口正，浅川隆重，濱田清，5-HT 3受容体拮抗剂 による便秘の発現, 日本病院薬剂師会杂倠誌，43，1219- 
1221 (2007).

9) 木村美智男, 宇佐美英績, 安田忠司，亀井桂太郎，磯谷 正敏，がん化学療法における副作用解析 - 5-HT 3拮 抗剂併用による便秘発生について一，医療薬学，33， 863-868 (2007).

10) 吉岡大樹, 山口㝳由美, 桃田美智, 平方尚之, 碇秀樹, オキシコドンによる悪心・嘔吐の予防を目的としたプロ
クロルペラジンとメトクロプラミド併用の検討, 日本病 院薬斉師会杂倠志，46，657-660 (2010).

11）林誠，杉村勇人, 菅幸生, 河原昌美, 相宮光二, 宮本謙 一, シスプラチン化学療法における吃逆の危険因子に関 する検討，医療薬学，35，89-95 (2009).

12) アロキシ®静注 $0.75 \mathrm{mg}$, 添付文書 第 1 版, 大鵬薬品 工業株式会社, 2010 年 1 月作成. 